\title{
THE NATURAL REFUGE POLICY FOR BT COTTON (Gossypium L.) IN PAKISTAN - A SITUATION ANALYSIS
}

\author{
Muhammad Sajjad Ali \\ The University of Agronomy and Veterinary Sciences \\ Marasti 59, Bucharest, Romania \\ email:ma4u70@hotmail.com
}

Received: 18.02.2013

\begin{abstract}
Bt cotton (event Cry1Ac) was formally commercialized in Pakistan in 2010. However, there has been an increasing trend of planting unauthorized Bt cotton germplasm in farmers' fields since 2003 with a high rate of adoption in the core cotton areas especially in the province Punjab. The transgenic cotton technology has provided the growers with substantial economic benefits and has reduced their dependence on pesticides for pest control, especially against Helicoverpa armigera (Hubner). However, keeping in view the capacity of this insect to develop resistance against novel chemical formulations, it is easily speculated that Bt toxin, too, is no exception. Refuge crop policy for mono transgenic crop events has helped in delaying the rate of resistance evolution in the target pests. Thus, in Pakistan, where planting of structured refuge crops along Bt cotton fields is not mandatory, the effectiveness and durability of Bt cotton technology may decrease due to a number of factors which are discussed in this review.
\end{abstract}

Key words: Gossypium hirsutum L., Bt cotton; cotton zone; natural refuge; Helicoverpa armigera; resistance evolution

\section{INTRODUCTION}

Pakistan is the fourth largest producer of cotton (Gossipium L.) after China, USA and India (A b i d et al. 2011). Over $15 \%$ of Pakistan's total cultivated area is devoted to this crop, whereas nearly $26 \%$ of all farmers grow cotton. Cotton contributes $6.9 \%$ of the value added in agriculture and about $1.4 \%$ to GDP (Anonymous, 2011). The insect pests, particularly the cotton bollworm (CBW), Helicoverpa armigera (Hubnar), has been a major yield retarding factor till recent past which resulted in an extensive application of pesticides, especially organophosphates and pyrethroids, in cotton to control CBW. In Pakistan, cotton alone consumed $70 \%$ of total pesticides.

The practice of often indiscriminate and heavy use of pesticides due to a rising pest pressure and an increasingly ineffectiveness of pesticides due to the development of resistance in target insects, especially $\mathrm{CBW}$, resulted not only in an economic burden for the resource of poor farmers but also caused environmental pollution.

Globally, the resistance in Helicoverpa sp. to synthetic pesticides began to appear in the late $80 \mathrm{~s}$ and early 90 s, which led to the research on developing an inbuilt plant mechanism of producing a lethal toxin against this pest through plant physiology. The result was the development of $\mathrm{Bt}$ cotton which expresses a variety of genes derived from a soil dwelling bacterium Bacillus thuringiensis Berliner (Bt). Bt cotton has proved an effective tool in reducing the damage by Helicoverpa armigera substantially, which ranged up to $80 \%$ of the yield loss in cases of severe infestation. The transgenic cotton was first commercialized in the USA, Australia and Mexico in 1996, to be followed by China (1997), South Africa (1998), Argentina (1998), India (2002), Colombia (2002), Brazil (2005), Costa Rica (2008), Burkina Faso (2009) as well as in Pakistan and Myanmar in 2010.

\section{The refuge crop concept}

In order to thwart off the threat of resistance evolution in Helicoverpa armigera, Bt plants are made to produce the protoxin $\mathrm{Bt}$ in concentrations high enough $\left(\mathrm{LD}^{99}\right)$ to ensure the mortality of the target pest. Moreover, a refuge crop policy is also adopted to provide a susceptible population of H.armigera.

The high dose/refuge crop strategy stipulates the production of insecticidal toxin in high concentration 
to ensure the mortality of the target insect in a setup of cotton cultivation where the cotton field is surrounded by a set limit of growing non-Bt cotton/other host plants of H.armigera as refuge. The susceptible insect population from the refuge crops, if synchronized in time and dimension, may help to produce heterozygous susceptible individuals. Thus, the refuge crop reduces the selection pressure upon the target pest and extends the effective life period of $\mathrm{Bt}$ cotton ( $\mathrm{H} \mathrm{u}$ a n g et al. 2006).

In the USA, the planting of Cry1Ac cotton was mandated with a compulsory refuge crop of conventional cotton which consisted of a $20 \%$ sprayed or $5 \%$ unsprayed conventional cotton area. Although the determinations of $5-20 \%$ of the crop area necessitate separate evaluations for the area-to-effectiveness relationship; however, this model of high dose/refuge crop is adopted in many countries for mono transgenic crop events, such as in Australia for Ingard ${ }^{\circledR}$ (Cry1Ab), for Cry1 Ab maize in Puerto Rico and South Africa, and for Cry1Ac cotton in India.

In Australia, the farmers choose among the five different refuge options (sprayed conventional cotton, unsprayed conventional cotton, sorghum, maize, or pigeon pea), each with a different area determined by the relative productivity of the refuge. The planting of the refuge crop has been strictly monitored in the USA and Australia where the rate of compliance has been $82 \%$ and $80 \%$ respectively for Cry 1 Ac cotton. However, Heliothine pests of cotton rapidly respond to novel chemical and biological formulations used for their control (A li , 2009). The Bt toxin is not an exception. Many studies have reported the inherent less susceptibility of Helicoverpa armigera to Bt toxins as compared with other insects of the same order ( $\mathrm{L}$ i a o et al. 2002) and the bollworm's potential to buildup resistance against $\mathrm{Bt}$ cotton in controlled field conditions has been documented (Downes et al. 2007; W u, 2007). Due to this reason, a number of cases regarding the evolution of resistance in Helicoverpa armigera are reported from the USA and Australia, too, though the high dose/refuge crop strategy was implemented with the required protocols there. The extraordinary capability of the Helicoverpa species to develop resistance against the chemicals used for its control is exhibited by the incidence of decrease in its susceptibility to Cry toxin (Carriere, 2010; D ow nes et al. 2010; Fit t, 2008).

Similarly in South Africa, a mono transgenic event carrying the crylAb gene to control the maize stem borer (H.armigera) was commercialized with a stipulated condition of setting up a $20 \%$ refuge crop by growers. However, due to non-compliance to the refuge requirement, planting of GM maize on large acreages and the absence of sufficient natural refuge crops have resulted in the development of resistance in Helicoverpa armigera against Cry1 $\mathrm{Ab}$ toxin.

The frequency of cases of resistance evolution is very high from the countries where the planting of mono transgenic crop events has been with a disregard/ non-compliance to the refuge crop set up (Table 1).

Table 1

Cases of resistance evolution in Helicoverpa armigera (Hub) from mono transgenic crop events

\begin{tabular}{|c|c|c|c|c|c|}
\hline No. & Country & Crop & Transgene & Insect sp. & References \\
\hline 1 & S.Africa & Maize & crylAb & B. fusca (Fuller) & Tabashnik et al. 2009. \\
\hline 2 & S.Africa & Maize & crylAb & $\begin{array}{c}\text { B. fusca; S. frugiperda (J.E. Smith); } \\
\text { H.zea; H. punctigera }\end{array}$ & $\begin{array}{c}\text { Krugeret al. } 2009 \\
\text { Van Rensburg, } 2007\end{array}$ \\
\hline 3 & Puerto Rico & Maize & $\operatorname{cry} 1 F$ & S. frugiperda & $\begin{array}{l}\text { Manjunath et al. } 1989 \\
\text { Storer et al. } 2010\end{array}$ \\
\hline 4 & China & Cotton & crylAc & H.armigera & Liu et al. 2009 \\
\hline 5 & India & Cotton & crylAc & H.armigera & $\begin{array}{l}\text { Ravi et al. 2005; } \\
\text { Bagla, } 2010\end{array}$ \\
\hline 6 & China & Cotton & crylAc & H.armigera & $\begin{array}{l}\text { He et al. } 2001 \\
\text { Xu et al. } 2001 \\
\text { Liu et al. } 2008\end{array}$ \\
\hline 7 & India & Cotton & crylAc & H.armigera & Gujar et al. 2007 \\
\hline 8 & India & Cotton & $\operatorname{crylAc}$ & P. gossypiella & Sanyasi et al. 2010 \\
\hline
\end{tabular}

The frequency of instances of surviving Helicoverpa armigera larvae on the Bt crop indicates the gradual accumulation of resistance alleles in the populations exposed to Bt crop cultures, especially in situa- tions where the selection pressure is intense due to no or insufficient presence of the refuge crop hosts.

However, the proponents of natural refuge plants argue that the strategy of structured and non-structured 
cotton/non-cotton refuge crops does not take into account other aspects of the pests' biology that may influence the ability of the refuge to dilute resistance alleles, such as oviposition preference by female Helicoverpa armigera moths due to the presence of allelochemicals in the new varieties of cotton and alternate host crops. The refuge crop strategy is also debatable in the context of the regional cropping pattern and may not serve the same purpose for every country because of the difference in the production environment, high diversity of cultivated crops, and land fragmentation.

Thus, in China a natural/zero refuge policy for Bt cotton (the mono transgenic cotton event CrylAc) was adopted to take advantage of the high mobility and active foraging of Helicoverpa armigera on a large number of alternate host plants, weeds and crop remnants. This insect can be found on more than 180 plant species other than cotton, including many of the major pulse crops, many vegetables as well as both dicotyledonous and monocotyledonous species ( $\mathrm{R} \mathrm{a} \mathrm{n} \mathrm{-}$ $\mathrm{j}$ i th et al. 2010). In China, due to land fragmentation and cultivation of a large variety of plants along with cotton fields, natural refuge plants support a larger population of Helicoverpa armigera than cotton ( $\mathrm{W} \mathrm{u}$ et al. 2002). The populations from these non-cotton hosts provide a substantial population of susceptible moths which dilutes the resistance allele frequency in the surviving population from Bt cotton (P A R C, 2008; Huang et al. 2010). However, in China in some regions where $\mathrm{Bt}$ cotton was planted extensively with less available alternate host crops, such as Xiajin County in Shandong province, tolerance to Bt cotton is reported to increase due to the incessant accumulation of common minor resistance genes in the natural populations of cotton bollworms. In some areas in southern Xinjiang Uygur Autonomous Region in China where the proportion of the area under cotton has reached $90 \%$ and alternate host plants are comparatively scarce, the risk of resistance evolution in CBW is highest.

In Pakistan planting of $\mathrm{Bt}$ cotton has been in practice, albeit in patches, across the cotton zone since 2003. The lack of regulatory biosafety rules and regulations as well as the absence of a field monitoring system resulted in a flush of illegal Bt varieties in the cotton growing regions. The illegal varieties contain the stolen Bt gene inserted into domestic cotton varieties by using the original $\mathrm{Bt}$ cotton as parental lines followed by random selection method. As reported by Sh a u k t et al. (2010) and A non y mous (2011), $80 \%$ and $50 \%$ of the cotton growing area in Sindh and Punjab provinces was under illegal and non-approved Bt cotton. An exotic source of Bt cotton named as Australian Bt was found in the field. In 2009/2010, more than $70 \%$ of the total cotton crop area was under non-approved Bt cotton germplasm (C a r r o 11 , 2009). The area under Bt varieties increased to $78 \%$ in 2010 ( $\mathrm{Z}$ a f f a r et al. 2012). Thus, a large area was already under Bt cotton till 2010 when the Punjab Seed Council approved $8 \mathrm{Bt}$ varieties [Cry1Ac event] for commercial cultivation. In the current cotton year 2012-13, more than $95 \%$ of the area of the total cotton acreage of 3.2 million hectares in Pakistan is under Bt cotton, which was mere 0.093 million hectares in 2005-06. While discussing the lack of refugia and resistance management in India, Dr K. R. Kranthi (K r a n th i , 2011) warned that with $90 \%$ of the cotton area under $\mathrm{Bt}$, resistance will develop sooner or later as there are reported cases of resistance evolution in Helicoverpa armigera from different cotton growing regions in India.

The purpose of this review is to analyze the factors which may determine the success or failure of the natural refuge policy for Bt cotton in Pakistan, especially in the cotton zone in Punjab which contributes more than $80 \%$ to the total cotton area. The aim was also to evaluate the magnitude of abundance (or absence) of alternate host plants required for the dilution of resistance allele frequency in Helicoverpa armigera (Hub).

\section{A successful adoption of bt cotton in Pakistan}

Pakistan is the $9^{\text {th }}$ country that adopted GMO or transgenic crop cultivation (TCC) and so far Bt cotton is the only GM crop which has been formally commercialized in the country. Field trials and evaluations for other transgenic crops, such as GM potato, rice and maize, are in progress at different stages in various research institutes.

In the cotton sector, the adoption of Bt cotton has provided with proven financial gains for the farmers and the textile industry. The consumption of pesticides on the cotton crop has been drastically reduced (Figure 1).On average; there are 3-4 sprays in Bt cotton fields as compared with $12-13$ sprays on conventional cotton varieties. 


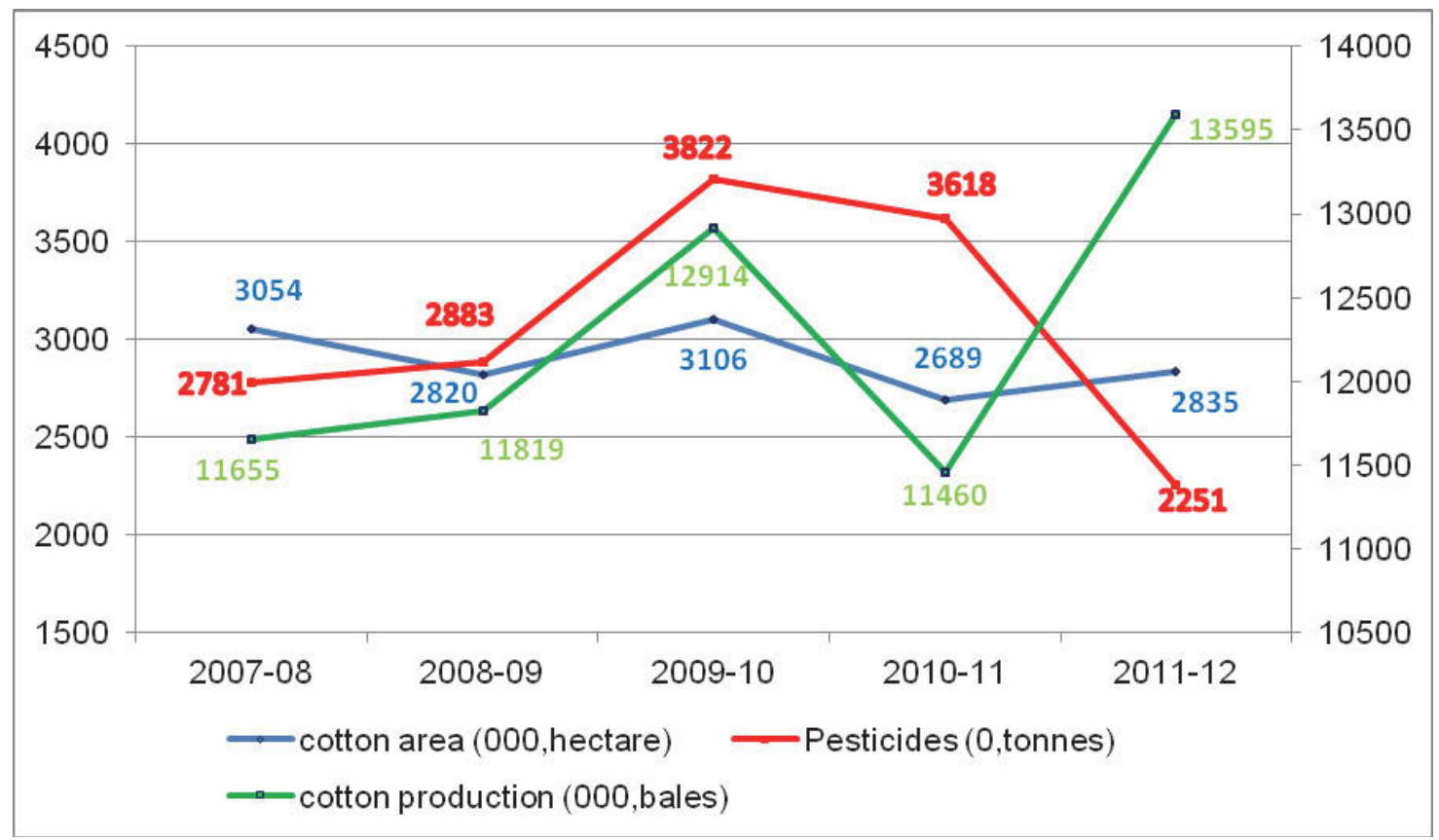

Fig. 1. The trend in the relationship between cotton acreage, consumption of pesticides, and production in bales. Source: Anonymous, 2012 .

In 2010-11 (July-March), the cotton acreage and production in bales decreased by $13.4 \%$ and $11.3 \%$, respectively. The reduction in acreage was in part due to the cultivation of other more profitable crops such as rice and sugarcane, extensive damage by sucking insect pests, and the spread of Cotton Leaf Curl Virus (CLCV) disease in many cotton areas. Besides, there were devastating floods in Punjab and Sindh where thousands of acres of the cotton crop were washed away. However, despite these odds, the cotton yield rose by $2.4 \% / \mathrm{ha}$. This increase is attributed to the growing of Bt cotton. In 2011 the adoption of Bt cotton resulted in a promising growth with $>135$ million bales produced, i.e. the productivity of the cotton crop rose by $18.6 \%$, although the increase in area under cotton crop was merely $5.4 \%$. At the same time, the consumption of pesticides decreased by $38 \%$. Evidently, the farmers gained economic benefits from the increase in yield/ha and from less expenditure on pesticides. The gains become even higher due to the cheaper price of Bt cotton seed, which ranges between $25-30 \$ / 5 \mathrm{~kg}$. This cost per $\mathrm{kg}$ of $\mathrm{Bt}$ seeds is approximately $14 \%$ higher than for the conventional varieties. However, it is nominal as compared with the Indian market where in the initial phase of commercialization $\mathrm{Bt}$ seeds were 3 times more expensive than nonBt seeds (PARC., 2008) .According to K o u s a r and Q a i m (2012), the gross profit per acre of Bt cotton, including all financial, health and environmental benefits, is US\$204, which translates into US\$1.7 billion for the entire Bt cotton area in Pakistan.
Although the increase in productivity and efficiency of the Bt cotton crop against Helicoverpa armigera is promising so far, but the history of the corelation among cotton, pesticides and Helicoverpa armigera in Pakistan reveals that there is a reason to be concerned about the sustainability and efficacy of $\mathrm{Bt}$ technology, especially due to the following factors:

I. Extensive Bt cotton acreage

II. Non-synchronization of the populations from various host plants

III. Scarcity of preferred refuge plants

IV. Prevailing illegal Bt cotton varieties

These factors are described with respect to the cotton growing regions of Pakistan, particularly the four core cotton districts.

\section{a. Extensive cultivation of Bt cotton with a comparative small area for refuge crops}

In Pakistan, refuge establishment is not mandatory and a natural refuge policy for Bt cotton is adopted, as has been the case in China. Areas of other host crops of Helicoverpa armigera such as maize, sorghum, tobacco, potato, okra, brinjal, pulses, and sunflower have been considered as sufficient to supply the susceptible population of Helicoverpa armigera.

However, the cropping landscapes in the cotton growing regions in China and Pakistan vary greatly. In China, the agricultural land is highly fragmented and a diversified pattern of different crops and weed hosts exists abundantly. At the county level, the cotton acreage is comparatively small as compared with 
the aggregated existing crop variety. The cropping pattern during the cotton crop season in Pakistan is also accompanied by the growing of other host crops; however, the acreage of alternate host plants is low

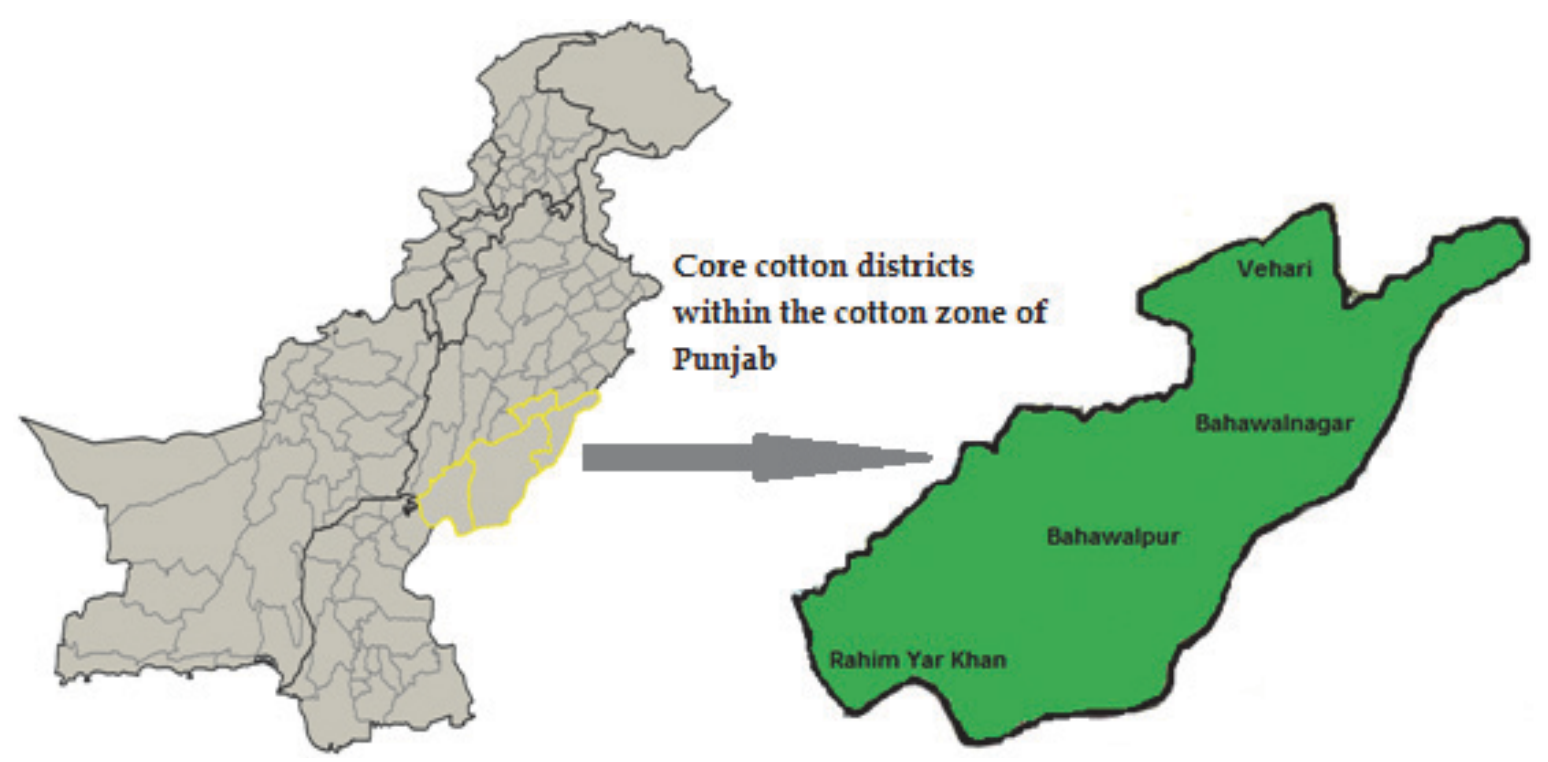

as compared with the cultivated cotton area at the village level, especially in the cotton zone in Punjab. The zone expands over Punjab and Sindh provinces (Fig. 2).

Fig. 2. The core cotton districts of the cotton zone in Punjab, Pakistan.

In 2012-13, the area of Bt cotton in Punjab is 2.56 million hectares and thus it covers approximately $62.59 \%$ of the Kharif (summer) crop area. The area intensity of cotton crop becomes more than $80 \%$ in the core cotton districts viz Bahawalnagar, Bahawalpur, Rahim Yar Khan and Vehari which comprise $42 \%$ of the total cotton acreage in Punjab (Fig. 3).

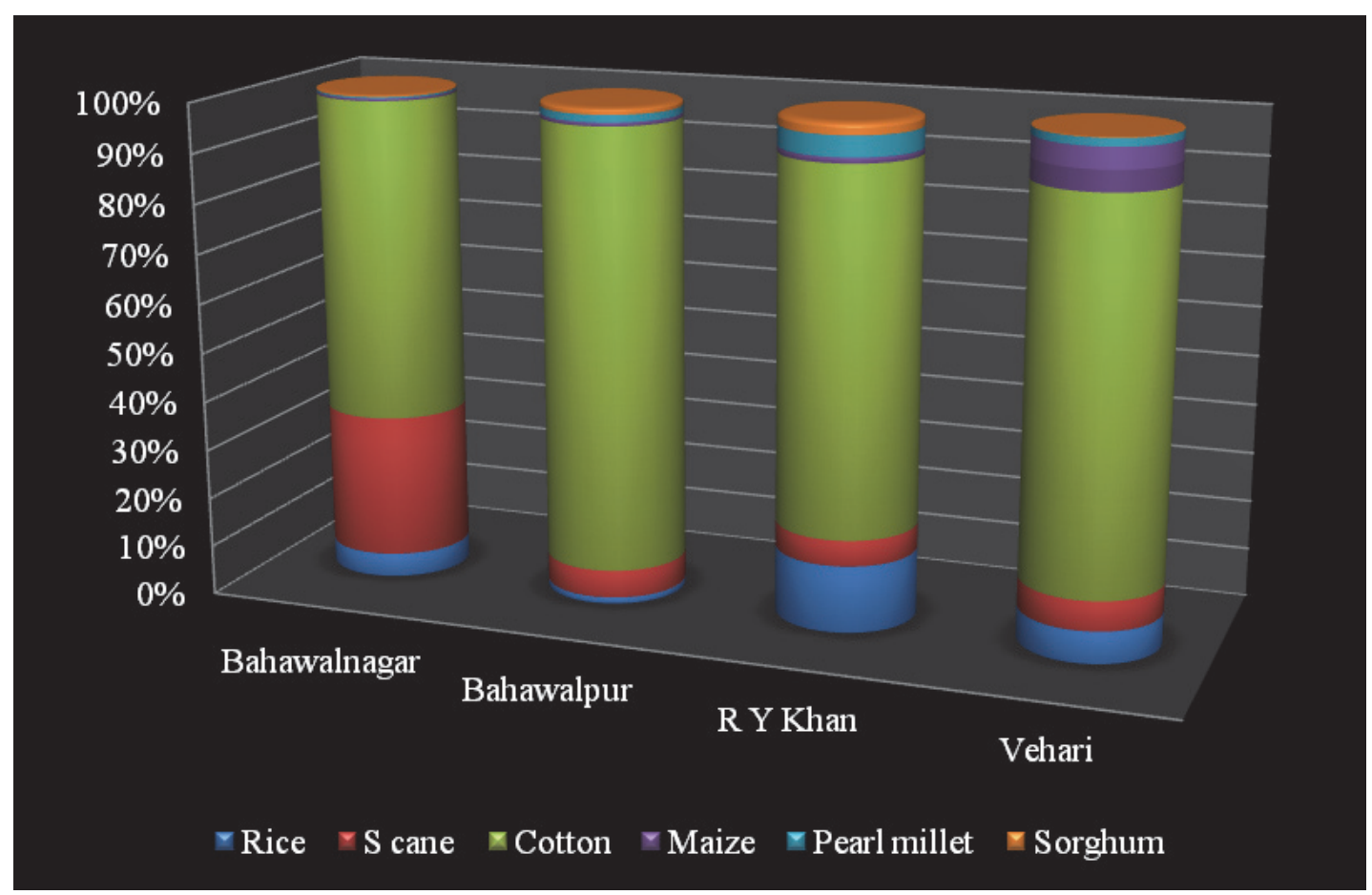

Fig. 3. District-wise percent area covered by major Kharif (summer) crops in the cotton zone. Source: AMIS (2012). 
The area of non-host crops, i.e. rice and sugar cane, is also shown to highlight the comparative area covered by Bt cotton. Due to intensive cultivation of Bt cotton in these districts, the combined area under alternate major host crops which overlap is far less than the $\mathrm{Bt}$ cotton area.

\section{b. Non-synchronizing moth populations from various host plants.}

The growing period of a number of host crop plants (e.g. maize, brinjal, ochra, legumes and other vegetables ) overlaps with that of the cotton crop and thus they may function as natural refuges for the American bollworm ( $\mathrm{W} \mathrm{u}$ et al. 2007; Li u et al. 2010; $\mathrm{Kruger}$ et al. 2009). In the presence of sufficient natural refuge crops during summer, subpopulations of Helicoverpa armigera develop through the first generation on spring weeds, winter legumes and on early sown sorghum or sunflower. At this time, the populations are relatively synchronized, but later in the summer a considerable overlap of generations occurs. The next 3-4 generations occur on cotton, although subpopulations will also be breeding on sorghum, maize and legumes over the summer. Hence, at any one time the Helicoverpa armigera population occurs as a complex mosaic of subpopulations developing on many host plants, at slightly different rates, with differing levels of mortality and fitness effects on the future fecundity as well as with considerable adult movement linking all subpopulations (D i 11 o n et al. 1996).

The concentration of Bt cotton crops in the four major cotton growing districts features mono cropping over vast tracts of agricultural land. According to the model presented by $\mathrm{Kranth}$ i et al. (2005), if the area under $\mathrm{Bt}$ cotton gets reaches $70-80 \%$ within a 100-200 kilometre radius, there is the highest probability of development of resistance in Helicoverpa armigera and the failure of the Bt cotton crop in 3-4 years. In the district of Bahawalpur, cotton crops cover $82 \%$ of the cultivated area during the summer season and thus the area covered by other crops is only $18 \%$, which shrinks even further for the crop plants which may act as alternate hosts (T a h i r , 2009).

Moreover, the crop phenology in the cotton zone exhibits insufficient availability of susceptible insect populations from alternate host crops.

The presence of $\mathrm{Bt}$ cotton in the field for a longer time period (March-December) continuously exposes multiple generations of H.armigera to the selection pressure.

The availability of adult moths of Helicoverpa armigera from non-cotton refuges, however, does not seem to synchronise with any resistant individuals emerging from the cotton fields (Figure 4), given that Helicoverpa armigera attacks mid to late age cotton plants.

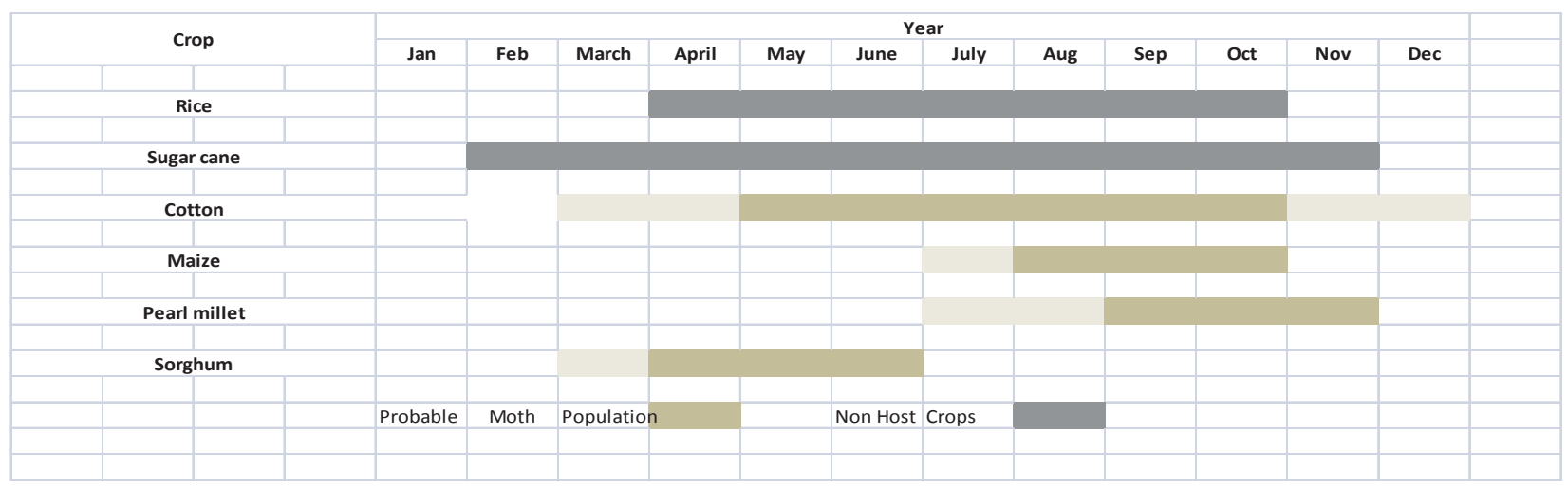

Fig. 4. The Crop Calendar in the cotton zone of Southern Punjab, Pakistan. Source: Author.

The major source of alternate refuge plants includes conventional cotton, maize, sorghum and pearl millet. The crop phenology indicates that the provision of the population of susceptible moths is possible only from 1-2 hosts exclusively at a particular time of the Bt cotton crop season, i.e. from sorghum in May and June, while from pearl millet/maize during August, September and October. It must be noted that these crops are of short duration and the early periods of crop growth (until Helicoverpa moths may lay eggs on them) and the fallow period/land preparation also shorten the period of sustaining a susceptible population of Helicoverpa sp. Moreover, the aggregate area under these major alternate host crops is far less than $10 \%$ of the Bt cotton area as shown in the above Fig. 3 .

\section{c. Scarcity of preferred refuge plants}

Female Helicoverpa armigera moths exhibit oviposition preferences on different hosts. According to L i u et al. (2004), female H.armigera larvae showed the highest egg-laying rate after feeding on cotton followed by corn, common bean tobacco, tomato, and 
hot pepper. The body weight, net reproductive rate and host suitability were the highest for cotton, along with the longest larval developmental stage on cotton. The results indicate relatively high nutrition in cotton as compared with the other host plants.

\section{Cotton> Maize $>$ Common Bean> \\ Tobacco $>$ Tomato $>$ Hot Pepper}

Due to an overwhelming presence of Bt cotton monoculture over a large area in the cotton zone in Punjab, the oviposition choice for the target insect is strictly limited to Bt cotton. Given the adoption rate and area under Bt cotton as compared with other host crops in these four districts, the moth population from non-Bt cotton must be minimum, which is contrary to the optimum condition for resistance management in CBW (C arriere et al. 2003; Carriere et al. 2004; W u et al. 2008; Hutchis on et al. 2010). He ad et al. (2010) concluded that in areas with extensive Bt cotton crops, refuges of non-Bt cotton play a minor role in the management of resistance to Bt cotton.

\section{d. Prevailing illegal Bt cotton varieties}

The variation in toxin production is a proven fact where the quantity of the toxin tends to decline as the plant matures. Other factors, such as nitrogen availability, temperature, humidity, inherent defence of the parent germplasm against pest attack, and soil $\mathrm{pH}$, also affect toxin production. The exposure to sub-optimal LD ${ }^{99}$ will greatly enhance the rate of development of the tolerance in the target population of Helicoverpa armigera. This inherent feature of Bt cotton technology, along with prevailing illegal Bt cotton germplasm in the farmers' fields, indicate a high probability of resistance evolution in CBW in the cotton growing areas in Pakistan. According to a survey by the Pakistan Agricultural Research Council (P A R C , 2008) [34], 40 percent of Pakistan's cotton region was sown under illegal $\mathrm{Bt}$ cotton varieties. It also revealed that there were almost $40 \mathrm{Bt}$ varieties, mostly with unknown genetic background. A high variation in the quantity of the toxin produced was also observed. Currently, many companies sell the illegal Bt varieties under various denominations such as $\mathrm{Bt} \mathrm{A} 1$, Bt $\mathrm{SJ} 1$, Bt 555, Bt 886, Bt 905,Bt 986, Bt Tarzan 1,Bt Tarzan 2, etc. Such illegal Bt varieties are from exotic sources and are given to farmers for cultivation without validating the purity, performance and proper production technologies according to the local environment. Farmers, who are mostly small farmers, are not so much aware of the harmful effect of these illegal untested varieties on their health and soils.

The factors such as a longer persistence of the Bt cotton crop, monoculture in the cotton zone, illegal Bt varieties as well as insufficient availability of overlapping generations of Helicoverpa armigera from non-cotton refuges greatly enhance the rate of development of resistance in the target insect (W a r dhaugh et al. 1980; Fitt et al. 1996; Sequeira et al. 2001; Green et al. 2003).

\section{Need for a structured refuge crop policy}

the agricultural landscape of Pakistan resembles most that of India due to the resemblance in the fragmentation of land and the intensity of various crops grown. Similar weather and soil conditions in the two adjacent cotton growing regions of Punjab in India and Pakistan offer an opportunity to examine the factors which compelled the Indian Ministry of Agriculture to adhere to a structured refuge policy up to 2005. From 2002-2005, the Indian Government bound every seed seller to enter into a contract with the purchaser of $\mathrm{Bt}$ cotton seed for the establishment of non-Bt cotton hybrids on at least $20 \%$ of the Bt cotton crop, or else there must be at least 5 rows of conventional cotton crop surrounding the Bt cotton area. It was mandated to prevent the development of resistance in H.armigera. However, the minimal compliance to this refuge policy by the farmers has resulted in reports of resistant individuals from various cotton growing regions in India. In the new policy of Mix bag refuge, 5\% of seeds of a conventional hybrid are provided separately in a small pouch found in the sale packet of Bt seed. It is based upon the idea that the planting of conventional seeds will provide a sufficient population of conventional plants in a Bt cotton field which may support a significant population of susceptible larvae of Helicoverpa armigera (Hub).

A similar policy must be adopted for the success of Bt cotton technology in Pakistan because the structured refuge policy for mono transgenic events have a proven success in different countries. The success of Bt mono transgenic technology in these countries have been the result of compliance to the refuge crop establisment by the farming community. This has helped to maintain the susceptibility of Helicoverpa armigera to the $\mathrm{Bt}$ toxin and after about 17 years of the commercialization of Bt events, the susceptibility of Helicoverpa armigera populations in these countries is still maintained. The natural refuge policy for $\mathrm{Bt}$ cotton (Cry1Ac) have resulted in a number of incidences of resistance development in target insects (W a n et al. 2012). It is in spite of the fact that the Chinese agricultural landscape offers a greater diversity and abundance of alternate host plants for the target insect.

The Bt cotton area in the cotton zone in Punjab well surpasses the combined area under natural refuge vegetation. The area becomes even more insufficient during the phases of harvest, fallow, land preparation and the early period of plants' growth until they become the available sites for female Helicoverpa armigera 
for egg laying. It is evident from the crop phenology and the cropping pattern in the cotton zone that at any given time of the year, the area under the natural refuge vegetation falls below $20 \%$ of the Bt cotton area in the effective refuge area (the area of foraging and egg laying by female Helicoverpa armigera moths). The insufficient density and large acreage under alternate host crops indicate that the resistance, when developed in a local population of Helicoverpa armigera, will rapidly spread across the cotton zone.

The purchase of Bt cotton seed must be accompanied by a description of planting a refuge crop. The compliance by the farming community can be enhanced by a regular and efficient field monitoring mechanism.

\section{Acknowledgements}

The facilities for access to bibliographic material and research articles provided by UASVM, Bucharest (Romania) are acknowledged and appreciated.

I am thankful to all those farmers in Punjab (Pakistan) who, during the field visits, provided me with valuable information about the current crop situation.

\section{REFERENCES}

Abid M., Ashfaq M., Hassan S., Fatima N. 2011. A resource use efficiency analysis of small Bt cotton farmers in Punjab, Pakistan. Pak. J. Agric. Sci. 48 (1) 65-71.

Agriculture statistics of Pakistan. Published by Agriculture Marketing Information Service., 2012. Directorate of Agriculture (Economics \& Marketing) Punjab, Lahore. http://www.amis.pk/Agristatistics/ Statistics.aspx

Ali M.I., and Luttrell R.G. 2009. Response estimates for assessing Heliothine susceptibility to Bt Toxins. J. Economic Entomol. 102: 1935-1947

A nony mous 2011. Economic Survey of Pakistan. Govt. Pakistan. Ministry of Food and Agriculture, Islamabad.

A nonymous 2012. Economic Survey of Pakistan. Govt. Pakistan. Ministry of Food and Agriculture, Islamabad.

B a g la P. 2010. Hardy cotton-munching pests are latest blow to GM crops. Science, 327:1439.

Carričre Y., Crowder D.W., Tabashnik B.E. 2010. Evolutionary ecology of insect adaptation to $\mathrm{Bt}$ crops. Evol Appl. 3: 561-573. http://dx.doi.org/10.1126/ science.327.5972.1439

Carriere Y., Ellers-Kirk C., Sisterson M., Antilla L., Withlow M., Dennehy T.J., Tabashnik B.E. 2003. Long-term regional suppression of pink bollworm by Bt cotton. Proceedings of the National Academy of Sciences (USA). 100: 1519-1523.

Carriere Y., Sisterson M., Tabashnik B.E. 2004. Resistance management for sustainable use of Bt crops in integrated pest management. Pages 65-95 in A. R. Horowitz and S. Ishaaya, editors. Insect pest management: field and protected crops. Springer-Verlag, New York, New York, USA.

Carroll J. Pakistan annual cotton report (Global Agricultural Information Network Report)., 2009. Washington, DC: US Department of Agriculture, Foreign Agricultural Service.

Dillon M.L., Fitt G.P., Hamilton J.G., Rochester W.A. 1996. A simulation model of wind-driven dispersal of Helicoverpa moths. Ecological Modelling. 86: 145-150. http://dx.doi.org/10.1016/0304-38 00(95)00042-9

Downes S., Mahon R., Olsen K. 2007. Monitoring and adaptive resistance management in Australia for Bt cotton: current status and future challenges. J. Invert. Pathol. 95: 208-213. http://dx.doi.org/10.1016/j. jip.2007.03.010

Downes S., Parker T., Mahon R. 2010. Incipient resistance of Helicoverpa punctigera to the Cry2Ab Bt toxin in Bollgard II cotton. PLoS ONE 5:e12567.

Fit t G.P. 2008. Have Bt crops led to changes in insecticide use patterns and impacted IPM? Integration of Insect-Resistant Genetically Modified Crops within IPM Programs, Progress in Biological Control. 5: 303-328. http://dx.doi.org/10.1007/978-1-4020-8373-0_11

Fitt G.P., Tann C. 1996. Quantifying the value of refuges for resistance management of transgenic Bt-cotton.( In:) Proceedings of the Eighth Australian Cotton Conference, Broadbeach. 77-83.

Green W.M., de Billot M.C., Joffe T., van Staden L., Bennett-Nel A., du Toit CLN., van der Westhuizen L. 2003. Indigenous plants and weeds on the Makhathini Flats as refuge hosts to maintain bollworm population susceptibility to transgenic cotton (Bollgard). Afr. Entomol. 11: 21-29.

Gujar G.T., Kalia V., Kumari A., Singh B.P., Mittal A., Nair R. 2007. Helicoverpa armigera baseline susceptibility to Bacillus thuringiensis Cry toxins and resistance management for Bt cotton in India. J. Invertebrate Pathol. 95, 214-219.

He D., Shen J., Zhou W., Gao C.2001. Using F2 genetic method of iso-female lines to detect the frequency of resistance alleles to Bacillus thuringiensis toxin from transgenic Bt cotton in cotton bollworm (Lepidoptera: Noctuidae). Cotton Sci. 13: 105-108.

Head G., Jackson R.E., Adamczyk J., Bradley J.R., Van Duyn J., Gore J., Hardee D.D. 2010. Spatial and temporal variability in host use by Helicoverpa zea as measured by analyses of stable carbon isotope ratios and gossypol residues. J. Applied Ecol. 47: 583-592.

Huang J.K., Mi J.W., Lin H., Wang Z.J., Chen R.J., Hu R.F., Rozelle S. 2010 A decade of Bt cotton in Chinese fields: assessing the direct effects and indirect externalities of Bt cotton adoption in China. Science China-Life Sci. 52: 981-991.

Huang J.K., Hai L., Hu R.F., Rozelle S.D., Pray C. 2006. Eight Years of Bt Cotton in Farmer Fields in China: Has the Bollworm Population Developed Resistance? Working paper, Center for Chinese 
Agricultural Policy (CCAP) of Chinese Academy of Sciences (CAS).

Hutchison W.D., Burkness E.C., Mitchell P.D., Moon R.D., Leslie T.W., Fleischer S.J. 2010. Abrahamson M. Area wide suppression of European corn borer with $\mathrm{Bt}$ maize reaps savings to non-Bt maize growers. Science, 330: 222-225.

Kouser S., Qaim M. 2012. Valuing financial, health and environmental benefits of $\mathrm{Bt}$ cotton in Pakistan. The International Association of Agricultural Economists (IAAE) Triennial Conference, Foz do Iguaçu, Brazil. http://dx.doi.org/10.1111/agec.12014

Kranthi K.R., Naidu S., Dhawad C.S., Tatwawadi A., Mate K., Patil E., Bharose A.A. 2005. Temporal and intra-plant variability of Cry1Ac expression in Bt-cotton and its influence on the survival of the cotton bollworm, Helicoverpa armigera (Hubner) (Lepidoptera: Noctuidae). Current Sci. 89: 291-298.

K ranth i K. 2011. Part-3: 10 years of Bt in India. [cited 2012 Oct 26];Available from: http://www.cotton247.com/ news/ci/?storyid=2171

Kruger M., Van Rensburg J.B.J., Van den B erg J. 2009. Perspective on the development of stem borer resistance to Bt maize and refuge compliance at the Vaalharts irrigation scheme in South Africa. Crop Prot. (28): 684-689. http://dx.doi.org/10.1016/j.cropro. 2009.04.001

Liao C.Y., Heckel D.G., Akhurst R. 2002. Toxicity of Bacillus thuringiensis insecticidal proteins for Helicoverpa armigera and Helicoverpa punctigera (Lepidoptera: Noctuidae), major pests of cotton. J. Invertebrate Pathol. 80: 55-63.

Liu F., Xu Z., Chang J., Chen J., Meng F., Zhu Y.C., Shen J. 2008. Resistance allele frequency to bt cotton in field populations of Helicoverpa armigera (Lepidoptera: Noctuidae) in China. J. Econ. Entomol. 101(3): 933-43.

Liu F., Xu Z., Zhu Y.C., Huang F., Wang Y. 2010. Evidence of field-evolved resistance to Cry1Ac-expressing Bt cotton in Helicoverpa armigera (Lepidoptera: Noctuidae) in northern China. Pest Manag Sci. 66: 155-161.

Liu Y.J., Song F.P., He K.L., Yuan Y., Zhang X.X., Gao P., Wang J.H., Wang G.Y. 2004. Expression of a modified cry1Ie gene in E. coli and in transgenic tobacco confers resistance to corn borer. Acta Bioch. Bioph. Sin. 36: 309-313.http://dx.doi.org/10.1093/abbs/ 36.4.309

Liu F., Xu Z., Zhu Y.C., Huang F., Wang Y., Li H., Ga o C. 2009. Evidence of field-evolved resistance to Cry1Ac-expressing Bt cotton in Helicoverpa armigera (Lepidoptera: Noctuidae) in northern China. Pest Manage. Sci. 66: 155-161.

Ranjith M.T., Prabhuraj A., Srinivasa Y.B. 2010. Survival and reproduction of natural populations of Helicoverpa armigera on Bt-cotton hybrids in Raichur, India. Current Sci. 99(11): 1602-1606.
Manjunath T.M., Bhatnagar V.S., Pawar C.S., Sithanantham S. 1989. Economic importance of Heliothis spp. in India and an assessment of their natural enemies and host plants. 197-228. In Proceedings of the Workshop on Biological Control of Heliothis: increasing the effectiveness of natural enemies. New Delhi, India.

Matten S.R., Head G.P., Quemada H.D. 2008. How government regulation can help or hinder the integration of Bt crops with IPM programs. [In:] Integration of insect resistant genetically modified crops within IPM programs. (ed.) by J. Romeis, A.M. Shelton, G.G. Kennedy, Springer, New York: 27-39.

PA R C. 2008. Status of cotton harboring Bt gene in Pakistan. Institute of Agri-Biotechnology \& Genetic Resources, Pakistan Agricultural Research Council (PARC), National Agricultural Research Centre, Islamabad, Pakistan.

Qaim M., Subramanian A., Naik G., Zilber$\mathrm{m}$ a n D. 2006. Adoption of Bt cotton and impact variability: insights from India. Applied Economic Perspectives and Policy. 28(1): 48-58.

Qiao F.B., Huang J.K., Rozelle S., Wilen J. 2010. Natural refuge crops, build-up of resistance, and zero-refuge strategy for Bt cotton in China. Science China-Life Sciences. 53: 1227-1238.

Ravi K.C., Mohan T.M., Manjunath G., Head B.V., Patil D.P.A., Greba K., Premalatha J. 2005. Relative abundance of Helicoverpa armigera (Lepidoptera: Noctuidae) on different host crops in India and the role of these crops as natural refuge for Bacillus thuringiensis cotton. Environ Entomol. 34: 59-69.

Sanyasi D., Gujar G.T. 2010. Field-evolved resistance to $B t$ toxin Cry1Ac in the pink bollworm, Pectinophora gossypiella (Saunders) (Lepidoptera: Gelechiidae), from India. Pest Management Science. 67(8): 898-903 doi: $10.1002 /$ ps.2127

Sequeira R.V., Playford C.L. 2001. Abundance of Helicoverpa armigera (Lepidoptera: Noctuidae) pupae under cotton and other crops in central Queensland: implications for resistance management. Aust. J. Entomol. 40: 264-269.

Shaukat A., Shahid H., Shahid., Ghulam M.A., Yusuf Z . 2010. Status of Bt cotton cultivation in major growing areas of Pakistan. J. Bot. 42(3): 1583-1594.

Storer N.P., Babcock J.M., Schlenz M. 2010. Discovery and characterization of field resistance to Bt maize: Spodoptera frugiperda (Lepidoptera: Noctuidae) in Puerto Rico. J Econ Entomol. 103: 1031-1038. doi: 10.1603/EC10040.

Tabashnik B.E., Van Rensburg J.B.J., Carriere Y. 2009. Field-evolved insect resistance to Bt crops: definition, theory, and data. J. Econ. Entomol. 102: 20112025. http://dx.doi.org/10.1603/029.102.0601

Tahir M., Tauqeer M., Rashid C., Shafiq B., Asif H., Matloob A., Khalid A., Shoaib T. 2009. Profile of district Bahawalpur with focus on livelihood related issues. Published by South Asia 
Partnership-Pakistan. [cited 2012 Nov 14]; Available at: http://www.sappk.org/publications/profiles/Profile_ Bahawalpur.pdf

Van Rensburg J.B.J. 2007. First report of field resistance by stem borer, Busseola fusca (Fuller) to Bt-transgenic maize. S Afr. J. Plant Soil. 24: 147-151. http://dx.doi.or g/10.1080/02571862.2007.10634798

Wan P., Huang Y., Wu H., Huang M., Cong S., Bruce E., Tabashnik B.E., Wu K. 2012 Increased frequency of pink bollworm resistance to Bt toxin Cry1Ac in China. PLoS ONE 7:e29975. doi:10.1371/journal.pone.0029975

Wardhaugh K.G., Room P.M., Greenup L.R. 1980. The incidence of Heliothis armigera (Hubner) and Heliothis punctigera (Wallengren) (Lepidoptera: Noctuidae) on cotton and other host plants in the Namoi valley of New South Wales. Bulletin of Entomological Research. 70, 113-132. http://dx.doi.org/10.1371/ journal.pone.0029975

Wu K.M., Guo Y.Y. 2005. The evolution of cotton pest management practices in China. Annu Rev. Entomol. 50: 31-52. http://dx.doi.org/10.1146/annurev.ento.50. 071803.130349

W u K.M. 2007. Monitoring and management strategy for Helicoverpa armigera resistance to Bt cotton in China J. Invertebr Pathol. 95: 220-223. http://dx.doi.org/10.1016/j.jip.2007.03.012

Wu K.M., Lu Y.H., Feng H.Q., Jiang Y.Y., Zha o J.Z. 2008. Suppression of cotton bollworm in multiple crops in China in areas with Bt toxin-containing cotton. Science, 321: 1676-1678.

Wu K.M., Guo Y.Y., Gao S.S. 2002. Evaluation of the Natural Refuge Function for Helicoverpa armigera (Lepidoptera: Noctuidae) within Bacillus thuringiensis Transgenic Cotton Growing Areas in North China. J. Econ. Entomol. 95(4): 832-837.

Xu X., Liu F., Chen J., Huang F., Andow D.A., Wang Y., Zhu Y.C., Shen J. 2009. Using an F2 screen to monitor frequency of resistance alleles to Bt cotton in field populations of Helicoverpa armigera (Hubner) (Lepidoptera: Noctuidae). Pest Manag. Sci. 65: 391-397.
Zaffar., Ihsan U11ah. 2012. Bt Cottons in Punjab: Current Status. [cited 2012 Nov 25]; Available at: http:// www.icac.org/tis/regional_networks/asian_network/ meeting_5/documents/papers/IqbalMZ.pdf

\section{Polityka dotycząca naturalnych ostoi w odniesieniu do upraw bawełny Bt (Gossypium L.) w Pakistanie - analiza sytuacji}

\section{Streszczenie}

Bawełna Bt (toksyna Cry1Ac) została oficjalnie wprowadzona na rynek w Pakistanie w 2010 roku. Jednak od 2003 roku istnieje tendencja wśród rolników do sadzenia na polach bawełny Bt $\mathrm{z}$ niedopuszczonym materiałem genetycznym, a wskaźnik rolników przechodzących na uprawę tego rodzaju bawełny jest wysoki, w szczególności w prowincji Pendżab. Stosowanie technologii uprawy transgenicznych odmian bawełny przyniosło producentom bawełny znaczne korzyści ekonomiczne oraz zmniejszyło ich zależność od pestycydów zwalczających szkodniki, w szczególności Helicoverpa armigera (Hubner). Jednak mając na względzie, że ten owad posiada zdolność rozwijania odporności na nowe preparaty chemiczne, łatwo można wysnuć wniosek, że toksyna Bt również nie stanowi wyjątku. Polityka dotycząca prowadzenia upraw stanowiących ostoje w przypadku stosowania monokulturowych upraw transgenicznych odmian bawełny pomogła opóźnić szybkość wytworzenia odporności w badanych szkodnikach. $\mathrm{Z}$ tego powodu w Pakistanie, gdzie nie ma obowiązku prowadzenia obok pól z bawełną Bt upraw o odpowiedniej strukturze stanowiących ostoję, efektywność i trwałość technologii uprawy bawełny Bt mogą się zmniejszyć z powodu szeregu czynników, które omówione są w niniejszym artykule. 